\title{
Insights and evidence gaps in girl-centered programming: A systematic review
}

\author{
Nicole Haberland \\ Population Council \\ Katharine McCarthy \\ Population Council \\ Martha Brady
}

Follow this and additional works at: https://knowledgecommons.popcouncil.org/departments_sbsr-pgy

Part of the Demography, Population, and Ecology Commons, Family, Life Course, and Society Commons, Gender and Sexuality Commons, International Public Health Commons, and the Maternal and Child Health Commons

How does access to this work benefit you? Let us know!

\section{Recommended Citation}

Haberland, Nicole, Katharine McCarthy, and Martha Brady. 2018. "Insights and evidence gaps in girlcentered programming: A systematic review," GIRL Center Research Brief no. 3. New York: Population Council. 
GIRL Center Research Brief

No. 3 April 2018

\section{INSIGHTS AND \\ EVIDENCE GAPS IN \\ GIRL-CENTERED \\ PROGRAMMING: \\ A SYSTEMATIC REVIEW}

NICOLE A. HABERLAND, KATHARINE J. MCCARTHY, AND MARTHA BRADY
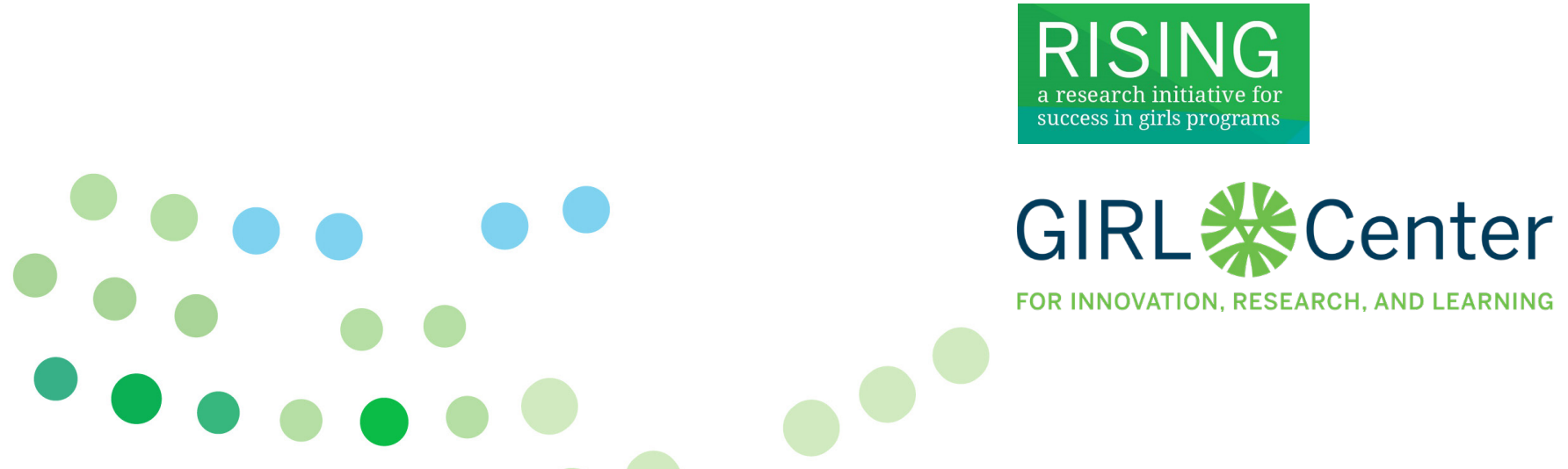

FOR INNOVATION, RESEARCH, AND LEARNING 
The Girl Innovation, Research, and Learning (GIRL) Center generates, synthesizes, and translates evidence to transform the lives of adolescent girls

popcouncil.org/girlcenter

GIRL Center Research Briefs present new knowledge on issues of current and critical importance and recommend future directions for research, policies, and programs.

This systematic review was undertaken as part of the Population Council's RISING program (a Research Initiative for Success in Girls programs), supported by the Nike Foundation, the John D. and Catherine T. MacArthur Foundation, and the David and Lucile Packard Foundation to build the evidence base for girl-centered programs. The content is solely the responsibility of the authors and does not necessarily represent the official views of the funding institutions.

Suggested citation: Haberland, Nicole A., Katharine J. McCarthy, and Martha Brady. 2018. "Insights and Evidence Gaps in Girl-Centered Programming: A Systematic Review," GIRL Center Research Brief No. 3. New York: Population Council.

Nicole A. Haberland is senior associate and Katharine J. McCarthy is staff associate at the Population Council. Martha Brady is director of the Reproductive Health Program at PATH.

\footnotetext{
This brief summarizes research from the Journal of Adolescent Health, in press, and the 2018 Annual Meeting of the Population Association of America.

Haberland, Nicole A., Katharine J. McCarthy, and Martha Brady. 2018. "A systematic review of adolescent girl program implementation in low- and middle-income countries: Evidence gaps and insights," Journal of Adolescent Health. In press. https://doi.org/10.1016/j.jadohealth.2017.11.294

Haberland, Nicole A., Katharine J. McCarthy, and Martha Brady. 2018. "A systematic review of adolescent girl program implementation in low- and middle-income countries." Poster presented at the 2018 Annual Meeting of the Population Association of America, April 26, 2018, Denver, CO
} 
Increased attention to the needs of adolescent girls has led to a growing number of programs in low- and middle-income countries (LMICs).

Questions remain, however, about what aspects of program design are most effective. This hinders efforts to effectively allocate resources, scale-up programs, and replicate results across settings. To address these issues, we conducted a systematic review to identify lessons learned and gaps in the evidence base.

\section{KEY FINDINGS}

1. Multicomponent programs tended to outperform single-component programs, although few studies controlled for duration of exposure to the intervention. There were too few studies to draw conclusions about the durability of program effects over time.

2. Longer program exposure improved program effectiveness and may contribute to the durability of program effects over time, although selection bias was a limitation in a number of studies.

3. Evidence on whether multilevel interventions enhance benefits for girls relative to single-level interventions was inconclusive. No identified studies assessed the relative effect of booster "add-ons" (versus no booster) or varied the saturation level of the program in communities.

4. Few evaluations of girl-centered programs to date have rigorously addressed implementation science questions, highlighting a robust and urgent research agenda for the future. 


\section{BACKGROUND}

The 1.2 billion young people aged 10-19 living today -the largest generation of adolescents ever-present the world with unprecedented potential for social and economic progress. With the majority of adolescents living in low- and middleincome countries (LMICs), identifying programs that prevent them from falling into or remaining in poverty is more pressing than ever. Girls, especially, are confronted with unique challenges, such as gender-based violence, child marriage, early pregnancy, and increased risks of HIV/AIDS. Today, it's hard to find a global health or development organization that isn't implementing programs or projects aimed at improving some aspect of girls' lives.

While understanding what works - and what does not work-is important to ensure that investment in girl-centered programming is evidence-informed, it is equally imperative to explore how and why these interventions work, for what girls, for which outcomes, and whether outcomes are sustained. ${ }^{1}$ Specifically, the field has limited answers to the following questions:

- Are multicomponent programs that combine different interventions-such as life-skills education and savings accounts-better at improving outcomes for girls relative to programs with only one type of intervention?

- What is the added value of involving individuals in addition to the girl herself, such as parents, guardians, husbands, etc. (i.e., multilevel interventions)?

- What is the threshold proportion of girls that is needed to participate in a program to bring about normative and behavior changes at the community level?

- Is a greater level of program exposure associated with greater programmatic benefit for girls?

- Can supplemental "booster" activities extend the benefits of a program after it ends?

We conducted a systematic review to identify lessons learned and gaps in evidence. This research was undertaken as part of the Council's RISING (a Research Initiative for Success in Girls programs) initiative, which builds the evidence base for best practices in girl-centered programs. 


\section{METHODOLOGY}

Four electronic databases (PubMed, CINAHL, EconLit, and Sociological Abstracts) were searched to identify studies published between 1990 and 2014 that evaluated health (i.e., sexual and reproductive health, HIV, and sexually transmitted infections [STIs]), social (education, violence, empowerment), or economic programs targeting adolescent girls (ages 10-24) in LMICs ( $N=77$ of 33,743 identified articles). We extracted information on the program objective, participants, setting, intervention content, program attributes, and outcomes. Outcomes of interest related to knowledge, attitudes/beliefs/norms, self-efficacy/agency, behaviors, or health or status outcomes (e.g., STIs, school enrollment, child marriage) across health, social, and economic domains. Studies that examined by design the relative effect of multicomponent versus single-component programs, multilevel versus single-level programs, boosters, and higher versus lower levels of saturation in the community and program exposure level, were included in the analysis $(\mathrm{N}=19)$.

Study quality was assigned based on type of study design, where randomized controlled trials (RCTs) were considered high quality, quasi-experimental designs or pre- and post-intervention assessments with a comparison group were considered medium quality, and cross-sectional, control-comparison data were considered low quality. This initial rating was adjusted based on whether there were other sources of unaddressed bias in the study, as defined by the Effective Public Health Practice quality assessment tool. ${ }^{2}$ The full methodology is described in Haberland, McCarthy, and Brady (2018). 


\section{KEY FINDING 1}

\section{MULTICOMPONENT PROGRAMS TEND TO OUTPERFORM SINGLE-COMPONENT PROGRAMS.}

Eight studies compared a single-component program (e.g., life skills) with a multicomponent version (e.g., life skills plus savings accounts) (Table 1). In total, five studies (two high-quality, two medium-quality, one low-quality) found stronger effects in the multicomponent arm. Of these, four were based on changes in behavior or impact related to work, violence, school, or marriage, and one examined changes in gender attitudes. Three studies (two high-quality, one medium-quality) did not find a difference between multicomponent and singlecomponent arms. Additionally, three studies assessed outcomes over multiple follow-up periods. Of these three, only one found that the multicomponent arm demonstrated greater effect durability for some outcomes over time. The main limitation to this analysis is that in several of the studies, the multicomponent arm (either likely or clearly) entailed more time with participating girls, raising the question of how much of the enhanced performance is attributable to multiple components, to greater exposure, or a combination of the two. The two studies that compared program variations that likely did not differ in the amount of time girls were exposed to the program did not find that the multicomponent arm performed better.

\section{KEY FINDING 2}

\section{LONGER PROGRAM EXPOSURE MAY MATTER FOR PROGRAM EFFECTIVENESS.}

Eight studies assessed the magnitude of program effects by exposure level (Table 2). Of these, seven studies (six medium-quality and one low-quality) provided evidence that longer exposure was associated with greater benefit, with results based on a range of outcome indicators. Additionally, two studies assessed the magnitude of program effect(s) by exposure level over multiple follow-up assessments. Both of these studies evaluated conditional cash transfer programs and found that girls with longer exposure demonstrated greater school enrollment or attainment, an effect that persisted over time. We note important limitations of some studies reviewed, such as the possibility of selection bias-that girls who chose to attend more sessions may have been more likely to do well regardless of how many hours of intervention they received. 
KEY FINDING 3

\section{THERE IS INSUFFICIENT EVIDENCE TO DETERMINE WHETHER MULTILEVEL INTERVENTIONS, BOOSTERS, OR COMMUNITY SATURATION LEVEL ENHANCE INTENDED OUTCOMES FOR GIRLS.}

Five studies compared a single-level program (e.g., program with girls only) with a multilevel version (e.g., program with girls plus an intervention with parents, family, or employers) (Table 3). We found mixed evidence with regard to whether multilevel programs outperform programs that engage girls only. Two studies (medium- and low-quality) found better outcomes in the multilevel arm-one assessing changes in physical fitness and the other assessing changes in gender attitudes. Two high-quality studies found the multilevel arm did not outperform the single-level arm. The remaining study found no effects for adolescent girls in our age group of interest regardless of study arm. Two programs compared multilevel and singlelevel study arms over multiple time-points; neither study provided evidence of more sustained program impact in the multilevel versus single-level arm.

There was also insufficient evidence to draw conclusions regarding questions of booster add-on components and community saturation level. We identified only one girl-centered program in an LMIC setting that included a booster component and no studies tested the relative benefit of its addition. ${ }^{3}$ Only one study described varying the saturation of the program as part of the study design; ${ }^{4}$ the analysis of these data is currently underway.

\section{KEY FINDING 4}

\section{FEW EVALUATIONS OF GIRL-CENTERED PROGRAMS TO DATE HAVE RIGOROUSLY ADDRESSED IMPLEMENTATION SCIENCE QUESTIONS, HIGHLIGHTING A ROBUST AND URGENT RESEARCH AGENDA.}

Despite a relatively large initial sample of evaluations of girl-centered programs in LMICs ( $\mathrm{N}=77$ ), only 19 studies provided information that examined or allowed examination of implementation science questions. Of included studies, 6 were high quality, 11 were moderate, and 2 were low quality. Studies generally provided limited information on the process of program implementation. For example, many studies did not include information on the number of hours and program length (i.e., dosage) in different study arms, or participant exposure to the intervention in practice. Such reporting limitations, in addition to methodological limitations, leave many implementation science questions unanswered and underscore the continued need for rigorous research to address questions related to what program attributes, as well as level of program exposure and saturation in the community, are most effective in producing intended outcomes for girls. 


\section{POLICY RECOMMENDATIONS}

As girl-centered programs are considered for replication, expansion, and scale-up, or new program ideas are innovated for pilots, it is critical that we know what does and does not work for girls, and equally important that we understand how and why programs have their effect. This evidence is vital to ensure that girls receive effective support and to guide the judicious use of limited resources. Based on the gaps identified in this review:

\section{We recommend a robust implementation research agenda. Such an 1. agenda includes rigorous studies that:}

- Compare multicomponent and single-component programs that hold program exposure constant

- Assess the effects of differential program exposure while addressing selection bias

- $\quad$ Compare multilevel with single-level program variations

- Test whether boosters can sustain program effects

- Assess what level of program saturation can lead to benefits for nonparticipants or change at the community level

- Are longer term, to understand whether/which implementation approaches are more likely to lead to sustained effects

- Assess a broader set of outcomes, to understand whether/which approaches are more likely to lead to a broader set of beneficial outcomes and whether the degree of change, or the durability of change, is affected

- $\quad$ Ascertain cost and measure cost-effectiveness.

Other implementation questions such as fidelity are of keen interest and also need further examination.

More studies on these questions would allow for the synthesis of evidence by program area and/or outcome, while higher-quality evidence can better inform whether there is a causal effect between intervention elements and outcomes.

\section{Well-documented program details are essential for maximizing resources to improve outcomes for girls.}

Most studies assessing girl-centered programs provided sparse information on program implementation, limiting the ability to address questions of program design and efficiency. There is a need for authors to publish full information regarding intervention design and implementation. A protocol for reporting the process of implementation would ensure standardization in the use of key terms as well as reported information.

Filling the program implementation evidence gap is essential to guiding investment of finite resources. The cost of conducting the high-quality research needed to answer these questions is substantial, but is vital to avert funding programs that do not work. 


\section{CONCLUSION}

This review looked at how the number of program components, involvement of supporting actors who influence the lives of girls, supplemental "booster" activities, intervention exposure level, and community saturation level influenced outcomes for girls. While findings suggest the importance of multicomponent programs and longer program exposure, each area requires further rigorous research to determine whether and under what circumstances they amplify impact. We call for future research to explicitly test implementation science questions to inform more effective use of resources and to improve outcomes for girls.

\section{KEY TERMS}

Girl-centered program-Explicitly targets or intends to reach adolescent girls, builds girls social, economic, education and/or health assets, intends to address girl-specific needs or vulnerabilities, measures outcomes at the level of the girl.

Implementation science-Methods to promote the adoption and integration of evidence-based practices into routine settings while maximizing program effectiveness, efficiency, quality, scale-up, and sustainability. ${ }^{5-7}$

Multicomponent-Programs that include more than one type of intervention for participants; for example, a program that includes both life-skills education and livelihoods training. Also referred to as combined (versus single-focus) programs.

Multilevel-Programs that reach not just the main beneficiary, but also include activities for actors who directly or indirectly affect their lives and well-being. Using the example of adolescent girls, this could include parents/guardians, husbands, siblings, teachers, etc.

Booster-Supplemental activities implemented with participants after the end of the main intervention with the aim of sustaining program effects.

Saturation-The proportion of individuals in a community eligible to participate (based on program-specific criteria) who actually participated in the intervention.

Exposure-Amount of a program's intended content that was received by participants.

Durability-The degree to which program effects are maintained over time. 
TABLE 1. ADOLESCENT GIRL PROGRAMS IN LOW- AND MIDDLE-INCOME COUNTRIES THAT ASSESSED MULTICOMPONENT‡ VERSUS SINGLE-COMPONENT INTERVENTION ARMS ( $\mathrm{N=8)}$

\begin{tabular}{|c|c|c|c|c|c|c|}
\hline \multirow{3}{*}{ Program } & \multirow{3}{*}{ Citation } & \multirow{3}{*}{ Intervention Arms ${ }^{\sigma}$} & \multicolumn{4}{|c|}{ Does Multicomponent Arm Perform Better?" } \\
\hline & & & \multirow{2}{*}{$\begin{array}{l}\text { Detailed Outcomes } \\
\text { (Direct comparison of intervention arms } \\
\text { or across arm evidence)" }\end{array}$} & \multicolumn{3}{|c|}{ Overall summary by study quality } \\
\hline & & & & Low & Medium & High \\
\hline \multirow{3}{*}{$\begin{array}{l}\text { Kishori Abhijan, } \\
\text { Bangladesh }\end{array}$} & \multirow[t]{3}{*}{ Amin et al. $2005^{8}$} & 1. APON (Education on health + legal rights) $(\mathbf{S})$ & \multirow{3}{*}{$\begin{array}{l}\text { Delayed marriage; Dowry payment; School retention; } \\
\text { Paid work } \uparrow\end{array}$} & & \multirow[t]{3}{*}{ Yes $^{\mathrm{c}}$} & \\
\hline & & 2. APON + microcredit to qualified members only (M1) & & & & \\
\hline & & $\begin{array}{l}\text { 3. CMES (Education on health and legal rights + } \\
\text { microcredit) (M2) }\end{array}$ & & & & \\
\hline \multirow{2}{*}{$\begin{array}{l}\text { Safe and Smart Savings, } \\
\text { Kenya and Uganda }\end{array}$} & \multirow[t]{2}{*}{ Austrian et al. $2013^{9}$} & 1. Savings accounts $(\mathbf{S})$ & \multirow{2}{*}{$\begin{array}{l}\text { Attitudes that condone GBV } \downarrow \text {; Experiences of GBV } \\
\text { (Savings Accounts only group experienced increased } \\
\text { GBV vs. no change in multicomponent); SRH } \\
\text { knowledge } 1 \text {; Ever HIV tested }\end{array}$} & & \multirow[t]{2}{*}{ Yes $^{b}$} & \\
\hline & & 2. Safe spaces girls group + savings accounts $(\mathbf{M})$ & & & & \\
\hline \multirow{3}{*}{$\begin{array}{l}\text { Training and wage } \\
\text { subsidy intervention, } \\
\text { Jordan }\end{array}$} & \multirow[t]{3}{*}{ Groh et al. $2012^{10}$} & 1. Job voucher (S1) & \multirow{3}{*}{$\begin{array}{l}\text { Employment (ever, current, months employed); } \\
\text { Hours worked last week; Work income; Life } \\
\text { evaluation (current, future); Mental health; Mobility; } \\
\text { Empowerment; Delayed marriage }\end{array}$} & & & \multirow[t]{3}{*}{$\mathrm{No}^{\mathrm{b}}$} \\
\hline & & 2. Employability training (S2) & & & & \\
\hline & & 3. Job voucher + employability training $(\mathbf{M})$ & & & & \\
\hline \multirow{3}{*}{$\begin{array}{l}\text { Supporting adolescent } \\
\text { orphan girls to stay in } \\
\text { school, Zimbabwe }\end{array}$} & \multirow[t]{3}{*}{ Hallfors et al. $2011^{11}$} & 1. School feeding program $(\mathbf{S})$ & \multirow{3}{*}{$\begin{array}{l}\text { School attendance } \uparrow \text {; Perception adults are caring; } \\
\text { Educational aspirations; Future expectations about } \\
\text { school completion } \uparrow ; \text { Gender equitable attitudes } \uparrow \text { \#; } \\
\text { Wife-beating endorsement; Think it's OK to ask } \\
\text { husband to use condom; Think it's not OK to have } \\
\text { sex as an adolescent; Waiting for sex until marriage/ } \\
\text { because of values; Waiting for sex because of } \\
\text { consequences } \uparrow ; \text { Ever sex; School dropout } \downarrow ; \\
\text { Delayed marriage } \uparrow \\
\text { \#Marginally significant at } p=0.07 \text {. }\end{array}$} & & & \multirow[t]{3}{*}{ Yes $^{a}$} \\
\hline & & $\begin{array}{l}\text { 2. School feeding program + school support (school } \\
\text { fees and supplies paid; school helper to meet } \\
\text { attendance requirement) (M) }\end{array}$ & & & & \\
\hline & & & & & & \\
\hline \multirow{2}{*}{$\begin{array}{l}\text { Siyakha Nentsha, } \\
\text { South Africa }\end{array}$} & \multirow[t]{2}{*}{ Hallman et al. $2011^{12}$} & 1. Basic (social \& health) education (S) & \multirow[b]{2}{*}{$\begin{array}{l}\text { Know where to get condoms; Know social grant } \\
\text { requirements; Improved budget and planning skills; } \\
\text { Attempts to open bank account; Saving behavior; } \\
\text { Remain sexually abstinent; Fewer number of sexual } \\
\text { partners; Undertake income-generating activity; } \\
\text { Self-esteem; Confidence in ability to get a condom; } \\
\text { Perceived social inclusion } \uparrow \text {; Obtain birth certificate } \uparrow\end{array}$} & & & \multirow[t]{2}{*}{$Y_{e s}^{a}$} \\
\hline & & 2. Basic education + financial education $(\mathbf{M})$ & & & & \\
\hline \multirow{2}{*}{$\begin{array}{l}\text { Sanitary pad and } \\
\text { puberty education } \\
\text { program, Ghana }\end{array}$} & \multirow{2}{*}{$\begin{array}{l}\text { Montgomery et al. } \\
2012^{13}\end{array}$} & 1. Puberty education (S) & \multirow[t]{2}{*}{ School attendance } & & \multirow[t]{2}{*}{$\mathrm{No}^{\mathrm{C}}$} & \\
\hline & & 2. Puberty education + menstrual pads $(\mathbf{M})$ & & & & \\
\hline
\end{tabular}




\begin{tabular}{|c|c|c|c|c|c|c|}
\hline \multirow{3}{*}{ Program } & \multirow{3}{*}{ Citation } & \multirow{3}{*}{ Intervention Arms ${ }^{\sigma}$} & \multicolumn{4}{|c|}{ Does Multicomponent Arm Perform Better?† } \\
\hline & & & \multirow{2}{*}{$\begin{array}{l}\text { Detailed Outcomes } \\
\text { (Direct comparison of intervention arms } \\
\text { or across arm evidence) })^{\varepsilon}\end{array}$} & \multicolumn{3}{|c|}{ Overall summary by study quality } \\
\hline & & & & Low & Medium & High \\
\hline \multirow{3}{*}{$\begin{array}{l}\text { Entre Amigas, } \\
\text { Nicaragua }\end{array}$} & \multirow[t]{3}{*}{ Peña et al. $2008^{14}$} & 1. Peer groups $(\mathbf{S})$ & \multirow[t]{3}{*}{ Self-esteem; Gender-equitable attitudes $\uparrow$} & \multirow[t]{3}{*}{ Yes $^{a}$} & & \\
\hline & & 2. Peer groups + mothers $(\mathbf{M} \mathbf{1})$ & & & & \\
\hline & & 3. Peer groups + mothers + soap opera (M2) & & & & \\
\hline \multirow{3}{*}{$\begin{array}{l}\text { Kishoree Kontha } \\
\text { (Adolescent Girls' } \\
\text { Voices), Bangladesh }\end{array}$} & \multirow[t]{3}{*}{ Scales et al. $2013^{15}$} & 1. Basic (SRH/life-skills, literacy) support (S1) & \multirow[t]{3}{*}{ Developmental assets } & & & \multirow[t]{3}{*}{$\mathrm{No}^{\mathrm{c}}$} \\
\hline & & 2. Livelihoods (basic + financial education) (S2) & & & & \\
\hline & & 3. Both (M) & & & & \\
\hline
\end{tabular}

${ }^{\ddagger}$ Multicomponent intervention refers to more than one type of intervention for the same participants.

" Program components indicated as: $\mathbf{S}$ = single-component arm ( $\mathbf{S} \mathbf{1}$ and $\mathbf{S} \mathbf{2}$ used to note multiple single-component arms, if applicable);

$\mathbf{M}=$ multicomponent arm (M1 and $\mathbf{M} \mathbf{2}$ refer to more than one multicomponent arm, if applicable).

"Outcomes: $\uparrow=$ multicomponent arm increases relative to single-component arm; no sign= no difference $\downarrow$ = multicomponent arm decreases relative to single-component arm .

Yes = multicomponent arm outperforms single-component arm; $\mathbf{N o}=$ multicomponent arm does not outperform single-component arm. Assessment based on

following levels of evidence for at least one outcome or at least one follow-up time-point:

$\mathrm{a}=$ Direct comparison of multicomponent vs. single component using significance test $(p<0.05)$.

$\mathrm{b}=$ Greater number of intended significant outcomes in multicomponent vs. control (or baseline) than in single component vs. control (or baseline).

${ }^{c}=$ Larger magnitude of effect in multicomponent vs. control (or baseline) relative to single component vs. control (or baseline). 
TABLE 2. ADOLESCENT GIRL PROGRAMS IN LOW- AND MIDDLE-INCOME COUNTRIES THAT ASSESSED MAGNITUDE OF PROGRAM EFFECT BY EXPOSURE LEVEL ${ }^{\prime}(\mathrm{N}=8)$

\begin{tabular}{|c|c|c|c|c|c|c|}
\hline \multirow{3}{*}{ Program } & \multirow{3}{*}{ Citation } & \multirow{3}{*}{ Exposure Groups ${ }^{\sigma}$} & \multicolumn{4}{|c|}{ Does longer exposure lead to better outcomes? ${ }^{\dagger}$} \\
\hline & & & \multirow{2}{*}{$\begin{array}{l}\text { Detailed Outcomes } \\
\text { (Direct comparison of exposure groups or } \\
\text { evidence across exposure groups)" }\end{array}$} & \multicolumn{3}{|c|}{ Overall summary by study quality } \\
\hline & & & & Low & Medium & High \\
\hline \multirow{8}{*}{$\begin{array}{l}\text { Better Life Options } \\
\text { Program, India }\end{array}$} & \multirow[t]{8}{*}{ Acharya et al. $2009^{16}$} & Intervention: & \multirow{8}{*}{$\begin{array}{l}\text { Independent decision-making } \uparrow \text {; Self-efficacy } \uparrow \text {; } \\
\text { Mobility } \uparrow \text {; Access to savings } \uparrow \text {; Gender-equitable } \\
\text { attitudes } \uparrow \text {; Gender-egalitarian work attitudes } \uparrow ; \\
\text { Awareness of SRH matters } \uparrow ; \text {; Communication with } \\
\text { parents (general topics); Communication with } \\
\text { parents (SRH topics) } \uparrow \text {; Preference for delayed } \\
\text { marriage } \uparrow ; \text {; Mean age at marriage } \uparrow\end{array}$} & & \multirow[t]{8}{*}{ Yes $^{\mathrm{bc}}$} & \\
\hline & & - Life-skills education & & & & \\
\hline & & - Livelihood training & & & & \\
\hline & & - Safe spaces girls groups & & & & \\
\hline & & - Regular attenders (half or more of sessions) (E1) & & & & \\
\hline & & - Irregular attenders (less than half of sessions) (E2) & & & & \\
\hline & & - Nonparticipants in intervention site (E3) & & & & \\
\hline & & - Control-site participants (E4) & & & & \\
\hline $\begin{array}{l}\text { Punjab Female School } \\
\text { Stipend Program } \\
\text { (FSSP), Pakistan }\end{array}$ & Alam et al. $2011^{17}$ & $\begin{array}{l}\text { Years of CCT exposure (to girl) conditional on school } \\
\text { attendance }(\mathbf{E})\end{array}$ & $\begin{array}{l}\text { Complete one grade of high school } \uparrow \text {; Probability of } \\
\text { delayed marriage } \uparrow\end{array}$ & & $Y \mathrm{~S}^{\mathrm{a}}$ & \\
\hline \multirow[t]{2}{*}{$\begin{array}{l}\text { PROGRESA/ } \\
\text { Oportunidades, Mexico }\end{array}$} & \multirow[t]{2}{*}{ Behrman et al. $2011^{18}$} & $\begin{array}{l}\text { 1. 18+ months of exposure to CCT (to family) } \\
\text { conditional on girls' school attendance vs. baseline (E1) }\end{array}$ & \multirow[t]{2}{*}{ Grade completion $\uparrow$; Employment } & & \multirow[t]{2}{*}{ Yes $^{c}$} & \\
\hline & & $\begin{array}{l}\text { 2. <18 months exposure to CCT (to family) conditional } \\
\text { on girls' school attendance vs. baseline (E2) }\end{array}$ & & & & \\
\hline \multirow[t]{2}{*}{$\begin{array}{l}\text { PROGRESA/ } \\
\text { Oportunidades, Mexico }\end{array}$} & \multirow[t]{2}{*}{ Behrman et al. $2012^{19}$} & $\begin{array}{l}\text { 1. One-year exposure to CCT (to family) conditional on } \\
\text { girls' school attendance (E1) }\end{array}$ & \multirow[t]{2}{*}{$\begin{array}{l}\text { School enrollment; Grade completion; Time devoted } \\
\text { to homework; Working for pay; Monthly wages }\end{array}$} & & \multirow[t]{2}{*}{ No bc } & \\
\hline & & $\begin{array}{l}\text { 2. Two years exposure to CCT (to family) conditional on } \\
\text { girls' school attendance (E2) }\end{array}$ & & & & \\
\hline \multirow[t]{5}{*}{ ISHRAQ, Egypt } & \multirow[t]{5}{*}{ Brady et al. $2007^{20}$} & $\begin{array}{l}\text { Intervention: girl centered spaces + literacy classes + } \\
\text { life-skills programs + sports clubs }\end{array}$ & \multirow{5}{*}{$\begin{array}{l}\text { Academic skills (writing, math, literacy) } \uparrow \text {; Gender- } \\
\text { equitable attitudes on marriage } \uparrow \text {; Desire for }<3 \\
\text { children } \uparrow \text {; Gender-equitable attitude index } \uparrow \\
\text { Decreased intent to circumcise daughters } \uparrow ; \text { Experience } \\
\text { of FGM/C } \downarrow \text {; Attitudes supportive of GBV } \downarrow \text {; Experience } \\
\text { of verbal abuse } \downarrow\end{array}$} & & \multirow[t]{5}{*}{ Yes $^{\mathrm{bc}}$} & \\
\hline & & 1. Full-term participants (30 months) (E1) & & & & \\
\hline & & 2. Dropouts (13-29 months) (E2) & & & & \\
\hline & & 3. Dropouts (<12 months) (E3) & & & & \\
\hline & & 4. Nonparticipants (0 months) (E4) & & & & \\
\hline $\begin{array}{l}\text { Female Secondary } \\
\text { School Assistance } \\
\text { Project (FSSAP), } \\
\text { Bangladesh }\end{array}$ & Khandker et al. $2003^{21}$ & $\begin{array}{l}\text { Continuous years of exposure (i.e., 1-4 years of } \\
\text { implementation in school) to CCT' (tuition paid to } \\
\text { school and stipend paid to girl directly) (E) conditional } \\
\text { on school attendance }\end{array}$ & Secondary school enrollment $\uparrow$ & Yes $^{\mathrm{a}}$ & & \\
\hline
\end{tabular}




\begin{tabular}{|c|c|c|c|c|c|c|}
\hline \multirow{3}{*}{ Program } & \multirow{3}{*}{ Citation } & \multirow{3}{*}{ Exposure Groups $^{\sigma}$} & \multicolumn{4}{|c|}{ Does longer exposure lead to better outcomes? ${ }^{\dagger}$} \\
\hline & & & \multirow{2}{*}{$\begin{array}{l}\text { Detailed Outcomes } \\
\text { (Direct comparison of exposure groups or } \\
\text { evidence across exposure groups)" }\end{array}$} & \multicolumn{3}{|c|}{ Overall summary by study quality } \\
\hline & & & & Low & Medium & High \\
\hline \multirow{8}{*}{$\begin{array}{l}\text { First Time Parents } \\
\text { Project, India }\end{array}$} & \multirow[t]{8}{*}{ Santhya et al. $2008^{22}$} & Intervention: & \multirow{3}{*}{$\begin{array}{l}\text { Autonomy and social support } \\
\text { Role in HH decision-making } \uparrow \text {; Mobility; Equitable } \\
\text { gender-role attitudes } \uparrow \text {; Nonacceptability of GBV; } \\
\text { Friends in marital village } \uparrow \text {; Peer support } \uparrow\end{array}$} & & Yes $^{b}$ & \\
\hline & & $\begin{array}{l}\text { Information provision (by outreach worker) + Social } \\
\text { support groups + Health service adjustments }\end{array}$ & & & & \\
\hline & & Two study sites: & & & & \\
\hline & & 1. Diamond Harbor ( $15 \%$ exposed to all 3 components; & \multirow{3}{*}{$\begin{array}{l}\text { Family planning and maternal health practices } \\
\text { Index of SRH knowledge } \uparrow \text {; Married women's } \\
\text { contraceptive use } \uparrow ; \text { ANC use } \uparrow \text {; Delivery } \\
\text { preparations } \uparrow ; \text { Facility-based birth; PNC check w/in } \\
6 \text { weeks } \uparrow ; \text { Early breastfeeding adoption } \uparrow\end{array}$} & & & \\
\hline & & $\begin{array}{l}\text { 51\% Information provision and group activities; } 20 \% \\
\text { information provision only) (E1) }\end{array}$ & & & & \\
\hline & & $\begin{array}{l}\text { 2. Vadodora (1\% exposed to all } 3 \text { components; } 9 \% \\
\text { information provision and group activities; } 13 \% \\
\text { information provision only) (E2) }\end{array}$ & & & & \\
\hline & & & \multirow{2}{*}{$\begin{array}{l}\text { Partner communication and support } \\
\text { Discussed contraceptive use with partner } \uparrow \text {; Partner } \\
\text { communication in disagreement } \uparrow \text {; Husband } \\
\text { supports wife in family conflicts }\end{array}$} & & & \\
\hline & & & & & & \\
\hline \multirow{11}{*}{$\begin{array}{l}\text { Go Girls! Initiative, } \\
\text { Botswana, Malawi, } \\
\text { Mozambique }\end{array}$} & \multirow[t]{11}{*}{ Underwood et al. $2011^{23}$} & Intervention: & \multirow{11}{*}{$\begin{array}{l}\text { HIV knowledge } \uparrow \text {; Adult-child communication } \uparrow \text {; } \\
\text { Relationship satisfaction with mother } \uparrow \text {; Reduction in } \\
\text { teachers asking for sex in exchange for favors } \uparrow \text {; Feel } \\
\text { safe in school; Legal literacy } \uparrow\end{array}$} & & \multirow[t]{11}{*}{ Yes $^{\mathrm{b}}$} & \\
\hline & & $\begin{array}{l}\text { 1. Structural level: training school personnel, access to } \\
\text { financial resources to girls + families }\end{array}$ & & & & \\
\hline & & $\begin{array}{l}\text { 2. Community: mobilization, local leadership } \\
\text { involvement }\end{array}$ & & & & \\
\hline & & 3. Family: adult-child communication & & & & \\
\hline & & $\begin{array}{l}\text { 4. Individual: community-based life skills (out-of-school } \\
\text { girls) and school-based life-skills education for boys } \\
\text { and girls (in school) }\end{array}$ & & & & \\
\hline & & 5. Radio component (all levels) (Malawi only) & & & & \\
\hline & & Implementation areas: & & & & \\
\hline & & $\begin{array}{l}\text { Botswana }(\mathbf{E 1}) \\
\text { Malawi (E2) }\end{array}$ & & & & \\
\hline & & Mozambique (E3) & & & & \\
\hline & & Participated in at least one activity: & & & & \\
\hline & & 18\% E1, 55\% E2, 24\% E3 & & & & \\
\hline
\end{tabular}

‡ Exposure level refers to level of participant adherence to the program, degree of program participation, or the length of time respondents receive the program.

${ }^{\sigma}$ E refers to exposure period assessed. $\mathbf{E} \mathbf{1}$ refers to exposure group 1 in study, E2 refers to exposure group 2, etc.

"Outcomes: 1 refers to increased magnitude of effect with longer exposure, no sign = no change with longer exposure, ${ }^{\downarrow}=$ lower magnitude of effect with longer exposure.

${ }^{+}$Yes = higher exposure arm outperforms lower exposure arm; $\mathbf{N o}=$ higher exposure arm does not outperform lower exposure arm. Higher exposure group outperforms lower exposure group using one of the following levels of evidence for at least one intervention time-point (if multiple):

a = Statistical comparison of intervention effect over time.

${ }^{b}=$ Greater number of intended significant outcomes in higher exposure group vs. control (or baseline) than in lower exposure group vs. control (or baseline)

${ }^{c}=$ Larger magnitude of effect in higher exposure group vs. control (or baseline) relative to lower exposure group vs. control (or baseline). 
TABLE 3. ADOLESCENT GIRL PROGRAMS IN LOW- AND MIDDLE-INCOME COUNTRIES THAT ASSESSED MULTILEVEL $¥$ VERSUS SINGLE-LEVEL COMPONENT INTERVENTION ARMS ( $=5$ )

\begin{tabular}{|c|c|c|c|c|c|c|}
\hline \multirow{3}{*}{ Program } & \multirow{3}{*}{ Citation } & \multirow{3}{*}{ Intervention Arms $^{\varpi}$} & \multicolumn{4}{|c|}{ Does Multilevel Arm Perform Better?† } \\
\hline & & & \multirow{2}{*}{$\begin{array}{l}\text { Detailed Outcomes } \\
\text { (Direct comparison of intervention arms or across arm } \\
\text { evidence)" }\end{array}$} & \multicolumn{3}{|c|}{ Overall summary by study quality } \\
\hline & & & & Low & Medium & High \\
\hline \multirow{4}{*}{$\begin{array}{l}\text { Training and wage } \\
\text { subsidy intervention, } \\
\text { Jordan }\end{array}$} & \multirow[t]{4}{*}{ Groh et al. $2012^{10}$} & 1. Job voucher (S1) & \multirow{3}{*}{$\begin{array}{l}\text { Across arm evidence ( } \mathrm{S} 1 \mathrm{vs.} \mathrm{control,} \mathrm{S2} \mathrm{vs.} \mathrm{control,} \mathrm{M} \mathrm{vs.} \mathrm{control)} \\
\text { does not show that participation in M arm leads to a greater } \\
\text { number or more sustained number of intended outcomes than } \\
\text { either single-level arm. }\end{array}$} & & & \multirow[t]{4}{*}{$\mathrm{No}^{b}$} \\
\hline & & 2. Employability training ( $\mathbf{S} \mathbf{2})$ & & & & \\
\hline & & 3. Job voucher + employability training $(\mathbf{M})$ & & & & \\
\hline & & & $\begin{array}{l}\text { Current employment (ever, current, months employed) (S1+); } \\
\text { Hours worked last week (S1+); Work income (S1+); Life evaluation } \\
\text { (current, future) (S1+, S2+); Mental health (S2+); Mobility (M+); } \\
\text { Empowerment; Delayed marriage }\end{array}$ & & & \\
\hline \multirow[t]{2}{*}{ CASPIAN, Iran } & \multirow[t]{2}{*}{ Kargarfard et al. $2012^{24}$} & 1. After-school physical activity program for girls (S) & \multirow{2}{*}{$\begin{array}{l}\text { Physiological health (resting heart rate, one-mile walk time, } \\
\text { max. oxygen intake, flexibility, abdominal muscle strength, and } \\
\text { endurance) } \uparrow ; \text { Upper-body muscle strength; BMl }\end{array}$} & & \multirow[t]{2}{*}{ Yes $^{\mathrm{a}}$} & \\
\hline & & 2. After-school physical activity + mothers (M) & & & & \\
\hline \multirow{3}{*}{$\begin{array}{l}\text { School feeding } \\
\text { program, Burkina Faso* }\end{array}$} & \multirow[t]{3}{*}{ Kazianga et al. $2009^{25}$} & 1. School meals (S) & \multirow{2}{*}{$\begin{array}{l}\text { New school enrollment; School absenteeism; Math ability; Time to } \\
\text { answer math questions; Cognitive development; Child labor }\end{array}$} & & & \multirow[t]{3}{*}{$\mathrm{No}^{\mathrm{b}}$} \\
\hline & & 2. Take-home ratios (conditional on attendance) (M) & & & & \\
\hline & & & *Note: Findings reported for girls ages 13 to 15. & & & \\
\hline \multirow{3}{*}{$\begin{array}{l}\text { Entre Amigas, } \\
\text { Nicaragua }\end{array}$} & \multirow[t]{3}{*}{ Peña et al. $2008^{14}$} & 1. Peer groups $(\mathbf{S})$ & \multirow[t]{3}{*}{ Self-esteem; Gender-equitable attitudes $\uparrow$} & \multirow[t]{3}{*}{ Yes $^{\mathrm{a}}$} & & \\
\hline & & 2. Peer groups + mothers $(\mathbf{M} \mathbf{1})$ & & & & \\
\hline & & 3. Peer groups + mothers + soap opera (M2) & & & & \\
\hline \multirow{6}{*}{$\begin{array}{l}\text { Exploring the World of } \\
\text { Adolescents (EWA), } \\
\text { EWA with parents } \\
(\text { EWA+), Vietnam }\end{array}$} & \multirow[t]{6}{*}{ Pham et al. $2012^{26}$} & 1. SRH education + gender content (EWA curriculum) $(\mathbf{S})$ & \multirow{2}{*}{$\begin{array}{l}\text { No clear pattern of larger magnitude of effect, significant number, } \\
\text { or sustained outcomes for M (vs. baseline) relative to S (vs. } \\
\text { baseline) across outcomes and follow-up times }\end{array}$} & & & \multirow[t]{6}{*}{$\mathrm{No}^{\mathrm{b}}$} \\
\hline & & \multirow{5}{*}{ 2. $\mathrm{SRH}+$ gender content + parent education $(\mathrm{EWA}+)(\mathbf{M})$} & & & & \\
\hline & & & Knowledge & & & \\
\hline & & & Pregnancy/contraceptive $(\mathrm{M}+)$; STIs; HIV (M+) & & & \\
\hline & & & Attitudes toward risk and protective behaviors & & & \\
\hline & & & $\begin{array}{l}\text { Extrinsic rewards; Intrinsic rewards (S+); Perceived severity: } \\
\text { pregnancy (M+); Perceived severity: HIV/AIDS (M+); Perceived } \\
\text { vulnerability: sex (S+); Perceived vulnerability: HIV/AIDS (S+); } \\
\text { Self-efficacy condom use; Self-efficacy abstinence; Response } \\
\text { efficacy; Response cost (S+) }\end{array}$ & & & \\
\hline
\end{tabular}

‡ Multilevel refers to programs that reach not just the primary target group of adolescent girls, but also include intervention activities for those who directly or indirectly affect girls' lives (e.g., parents, brothers, partners, community members).

${ }^{\sigma}$ Program components indicated as: $\mathbf{S}$ = single-level arm ( $\mathbf{S} \mathbf{1}$ and $\mathbf{S} \mathbf{2}$ used to note multiple single-level arms, if applicable); $\mathbf{M}=$ multilevel arm (M1 and $\mathbf{M} \mathbf{2}$ refer to more than one multilevel arm, if applicable),

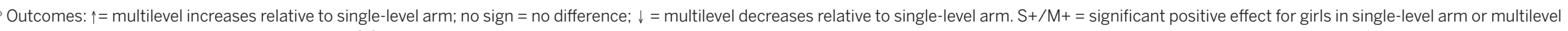
arm vs. girls in control/comparison group at $\mathrm{p}<0.05$.

Yes = multilevel arm outperforms single-level arm; $\mathbf{N o}=$ multilevel arm does not outperform single-level arm. Assessment based on following levels of evidence for at least one outcome or at least one follow-up time-point.

$\mathrm{a}=$ Direct comparison of multilevel vs. single level using significance test $(\mathrm{p}<0.05)$.

${ }^{b}=$ Greater number of intended significant outcomes in multilevel vs. control (or baseline) than in single level vs. control (or baseline). 
REFERENCES

1. Department for International Development \& Girl Hub. Adolescent Girls: Expert Meeting. October 2012

2. Quality Assessment Tool. Effective Public Health Practice Project. http://www.nccmt.ca/knowledgerepositories/search/14.

3. No Means No Worldwide program. https://www.nomeansnoworldwide.org/research/.

4. Baird, S., C. Mclntosh, and B. Ozler. 2011. "Cash or condition? Evidence from a cash transfer experiment," Quarterly Journal of Economics 126(4): 1709-1753.

5. National Institutes of Health, Implementation Science Information and Resources. 2017. Washington, DC Fogarty International Center.

6. Padian, N., C. Holmes, S. McCoy, R. Lyerla, P. Bouey, and E. Goosby. 2011. "Implementation science for the US President's Emergency Plan for AIDS Relief (PEPFAR)," Journal of Acquired Immune Deficiency Syndrome 56(3): 199-203.

7. Peters, H., N.T. Tran, and T. Adam. 2013. “Implementation Research in Health: A Practical Guide." Alliance for Health Policy and Systems Research. Geneva: World Health Organization.

8. Amin, S. and L. Suran. 2005. “Program efforts to delay marriage through improved opportunities: Some evidence from rural Bangladesh." New York: Population Council.

9. $\quad$ Austrian, K. and E. Muthengi. 2013."Safe and smart savings products for vulnerable adolescent girls in Kenya and Uganda: Evaluation report." Nairobi: Population Council.

10. Groh, M., N. Krishnan, D. McKenzie, and T. Vishwanath. 2012. "Soft skills or hard cash? The impact of training and wage subsidy programs on female youth employment in Jordan." Policy Research Working Paper 6141. Washington, DC: World Bank Group. doi: 10.1596.1813-9450-6141.

11. Hallfors, D., H. Cho, S. Rusakaniko, et al. 2011. "Supporting adolescent orphan girls to stay in school as HIV risk prevention: Evidence from a randomized controlled trial in Zimbabwe," American Journal of Public Health 101: 1082-1088. doi: 10.2105/AJPH.2010.300042.

12. Hallman, K. and E. Roca. 2011. "Siyakha Nentsha: Building economic, health, and social capabilities among highly vulnerable adolescents in KwaZulu-Natal, South Africa." New York: Population Council.

13. Montgomery, P., C.R. Ryus, C.S. Dolan, et al. 2012. "Sanitary pad interventions for girls' education in Ghana: A pilot study," PLoS One 7:e48274. doi: 10./1371/journal.pone.0048274

14. Peña, R., M. Quintanilla, K. Navarro, et al. 2008. "Evaluating a peer intervention strategy for the promotion of sexual health-related knowledge and skills in 10- to 14-year-old girls. Findings from the "Entre Amigas" project in Nicaragua," American Journal of Health Promotion 22(4): 275-281. doi: 10.4278.06012310R3.1.

15. Scales, P.C., P.L. Benson, L. Dershem, et al. 2013. "Building developmental assets to empower adolescent girls in rural Bangladesh: Evaluation of project Kishoree Kontha," Journal of Research on Adolescence 23 171-84. doi: 10.1111/j.1532-7795.2012.00805x.

16. Acharya R., S. Kalyanwala, S. Jejeebhoy, et al. 2009. "Broadening girls' horizons: Effects of a life skills education programme in rural Uttar Pradesh." New Delhi: Population Council.

17. Alam, A., J.E. Baez, X.V. Del Carpio. 2011. "Does cash for school influence young women's behavior in the longer term? Evidence from Pakistan." Policy Research Paper 5669. Washington, DC: World Bank Group. doi: 10.1596/1813-9450-5669.

18. Berhman, J.R., S.W. Parker, and P.E. Todd. 2011. "Do conditional cash transfers for schooling generate lasting benefits? A five-year follow-up of PROGRESA/ Oportunidades," Journal of Human Resources 46: 203-36. doi: 10.1353/ jhr.2011.0028.

19. Behrman, J.R., J. Gallardo-Garcia, S.W. Parker, et al. 2012. "Are conditional cash transfers effective in urban areas? Evidence from Mexico." Education Economics 20: 233-59. doi:10.1080/09645292.2012.672792.

20. Brady, M., R. Assad, B. Ibrahim, et al. 2007. "Providing new opportunities to adolescent girls in socially conservative settings: The Ishraq program in rural Upper Egypt." New York: Population Council.

21. Khandker, S., M. Pitt, and F. Nobuhiko. 2003. "Subsidy to promote girls' secondary education: The female stipend program in Bangladesh.” Munich Personal RePEc Archive No. 23688. Munich University Library.

22. Santhya, K.G., N. Haberland, A. Das, et al. 2008. "Empowering married young women and improving their sexual and reproductive health: Effects of the First-time Parents Project," New Delhi: Population Council.

23. Underwood, C. and H. Schwandt. 2011. “Go Girls! Initiative Research Findings Report: Data from the 2009 Baseline survey, 2009-10 Process Evaluation and 2010 Endline Survey in Botswana, Malawi and Mozambique." Baltimore: John Hopkins Bloomberg School of Public Health/Center for Communication Programs.

24. Kargarfard, M., R. Kelishadi, V. Ziaee, et al. 2012. "The impact of an after-school physical activity program on health-related fitness of mother/daughter pairs: CASPIAN study," Preventive Medicine 54: 219-223. doi: 10.1016/j.ypmed.2012.01.010.

25. Kazianga, H., D. de Walque, and H. Alderman. 2009. "Educational and health impacts of two school feeding schemes: Evidence from a randomized trial in rural Burkina Faso." Policy Research Working Paper 4976. Washington, DC: World Bank Group. doi: 10.1596/1813-9450-4976.

26. Pham, V., H. Nguyen, L.H. Tho, et al. 2012. "Evaluation of three adolescent sexual health programs in $\mathrm{Ha}$ Noi and Khanh Hoa Province, Vietnam," AIDS Research and Treatment 1-12. doi: 10.1155/2012/986978. 


\section{GIRL Center}

FOR INNOVATION, RESEARCH, AND LEARNING

The Girl Innovation, Research, and

Learning (GIRL) Center generates,

synthesizes, and translates evidence to

transform the lives of adolescent girls

popcouncil.org/girlcenter 